\title{
Komposisi Echinodermata Di Rataan Litoral Terumbu Karang Pantai Krakal, Gunung Kidul, Yogyakarta
}

\author{
Ken Suwartimah, Dwi Saniscara Wati, Hadi Endrawati, Retno Hartati* \\ Departemen Ilmu Kelautan, Fakultas Perikanan dan Ilmu Kelautan,Universitas Diponegoro \\ Kampus Tembalang, Semarang 50275 Telp/Fax. 024-7474698 \\ Email : retnohartati.undip@yahoo.com
}

\begin{abstract}
Abstrak
Echinodermata merupakan salah satu komponen penting dalam hal keanekaragaman fauna di daerah terumbu karang. Hal ini karena terumbu karang berperan sebagai tempat berlindung dan mencari makan bagi fauna Echinodermata. Salah satu penyebaran biota ini adalah di perairan rataan terumbu karang Pantai Selatan di Pantai Krakal, Gunung Kidul, Yogyakarta. Tujuan penelitian ini adalah untuk mengetahui species dan kelimpahan Echinodermata di Pantai Krakal, Kabupaten Gunung Kidul, Yogyakarta. Pengambilan sampel pada penelitian ini menggunakan metode transek kuadrat dengan ukuran $1 \mathrm{~m}^{2}$. Hasil pengamatan ditemukan beberapa species dari 3 kelas dari filum Echinodermata, antara lain 3 species dari kelas Echinoidea, 3 species dari kelas Ophiuroidea, dan 1 species dari kelas Asteroidea. Hasil penelitian menunjukkan kelimpahan individu tertinggi penelitian adalah Ophiocoma scolopendrina $\left(4.01 \mathrm{ind} . / \mathrm{m}^{2}\right)$ dan terendah adalah Archaster typirus ( 1 ind. $/ \mathrm{m}^{2}$ ).
\end{abstract}

Kata Kunci : Echinodermata, Ophiocoma scolopendrin, Archaster typirus, Krakal, Gunung Kidul

\begin{abstract}
Echinodermata is a important ecosystem component in terms of the diversity of fauna in the coral reefs. This is because the coral reefs act as a refuge and feeding ground for the fauna of the Echinoderms. One of echinoderm habitat is reef flat waters of Krakal Beach, Gunung Kidul, Jogjakarta. The purpose of this research is identify and determine the abundance of Echinoderms. Purpossive sampling method was applied. The samples were taken using $1 \mathrm{~m}^{2}$ transect squares. There were 3 classes of Echinodermata found, i.e. 3 species of Echinoidea, 3 species of Ophiuroidea, and 1 species of Asteroidea. The result showed that the highest was Ophiocoma scolopendrina (4,01 ind. $/ \mathrm{m}^{2}$ and the lowest was Archaster typirus (1 ind. $\left./ \mathrm{m}^{2}\right)$
\end{abstract}

Keywords : Echinodermata, komposisi, Krakal Beach, Gunung Kidul

\section{PENDAHULUAN}

Echinodermata merupakan salah satu komponen penting dalam hal keanekaragaman fauna di daerah terumbu karang (Yusron, 2010). Hal ini karena terumbu karang berperan sebagai tempat berlindung dan tempat pakan bagi fauna Echinodermata. Secara ekologi fauna Echinodermata berperan sangat penting dalam ekosistem terumbu karang, terutama dalam rantai makanan (food chains), karena biota tersebut umumnya sebagai pemakan detritus dan predator.

Echinodermata tersebar hampir di seluruh perarairan Indonesia. Salah satu penyebaran biota ini adalah di perairan rataan terumbu karang Pantai Selatan di daerah Gunung Kidul. Echinodermata yang umum dijumpai di perairan ini adalah bintang mengular, teripang, bulu babi dan bintang laut. Hal ini dikarenakan topografi pantai selatan di Gunung Kidul merupakan daerah rataan terumbu karang yang tersebar luas dan merata di sepanjang deretan pantai. Di dalam ekosistem terumbu karang juga dijumpai berbagai species ikan ekonomis konsumsi, ikan hias, moluska, krustasea, echinodermata dan biota lainnya (Triutami, 2009).

Echinodermata merupakan biota penghuni terumbu karang yang cukup menonjol, ketersediaan pakan di rataan terumbu karang menjadi salah faktor melimpahnya biota echinodermata di rataan terumbu karang, di samping itu rataan terumbu karang juga menjadi habitat biota ini untuk berlindung dari predator.

Kerusakan habitat seperti terumbu karang dikhawatirkan dapat menyebabkan penurunan populasi Echinodermata. Adapun penyebab kerusakan terumbu karang yang berdampak

$\begin{array}{llll}* \text { *Corresponding author } & \text { http://ejournal.undip.ac.id/index.php/buloma } & \text { Diterima/Received } & : 31-01-2017 \\ \text { buloma.undip@gmail.com } & & \text { Disetujui/Accepted } & : 11-03-2017\end{array}$


langsung terhadap Echinodermata diantaranya: penambangan karang untuk bahan bangunan, pembuatan kapur, penggunaan bahan peledak untuk menangkap ikan dan aktifitas wisata bahari.

Pantai Krakal merupakan salah satu pantai wisata yang banyak dikunjungi wisatawan lokal dan wisatawan mancanegara dimana pengunjungnya meningkat setiap tahun (Dinas Pariwisata Daerah dan Kebudayaan Kabupaten Gunung Kidul, 2007). Dengan meningkatnya pengunjung wisata di Pantai Krakal dapat menjadi ancaman kerusakan habitat Echinodermata yang dapat mengakibatkan menurunnya populasi Echinodermata di pantai tersebut. Sampai saat ini belum ada penelitian yang mengidentifikasi hewan-hewan echinodermata pada daerah rataan terumbu karang di pantaip-antai di Gunung Kidul, terutama di Pantai Krakal, sehingga tujuan penelitian ini adalah untuk mengidentifikasi species dan kelimpahan Echinodermata di Pantai Krakal, Kabupaten Gunung Kidul, Daerah Istimewa Yogyakarta.

\section{MATERI DAN METODE}

Materi penelitian adalah semua hewan yang termasuk filum Echinodermata yang ditemukan di Pantai Krakal, Gunung Kidul, Yogyakarta (Gambar 1). Pengambilan data dan sampel pada penelitian ini menggunakan metode transek kuadrat dengan ukuran 1x1 meter (Yusron, 2010). Tali transek ditarik tegak lurus dari pantai ke arah laut sepanjang 100 meter pada saat air laut surut atau menjelang surut terendah dikarenakan saat surut terendah mencapai 100 meter dari garis pantai, dengan 3x titik pengamatan dalam setiap stasiunnya (titik ke-1: 0-10 m; titik ke-2: 50-60 m; dan titik ke-3 100-110 m). Titik ke-1 berada di dekat daerah estuarin pada kedalaman $0-5 \mathrm{~cm}$, merupakan area yang sangat sedikit air. Titik ke-2 merupakan area yang air laut dengan kategori sedang dengan kedalaman 5-10 cm, dan titik ke-3 merupakan area yang masih tergenang saat pasang surut dengan kedalaman 10-30 cm. Penentuan titik ini berdasarkan kedalaman perairan saat pasang surut dan diduga telah memiliki kondisi fisik ataupun biologis yang berbeda pada kelimpahan biota laut. Identifikasi sampel dilakukan dengan cara mengamati ciri-ciri morfologi secara langsung Pengamatan karakter morfologi seperti bentuk kaki tabung dan jumlah lengan untuk kelas Asteroidea, bentuk lengan dan tentacle scale untuk kelas Ophiuroidea, keberadaan anus dan bentuk ambulakral untuk kelas Echinoidea dengan mengacu Fell (1960),
Clark \& Rowe (1971), Colin \& Arneson (1995), dan Gosliner et al. (1996).

Kelimpahan Individu adalah jumlah individu per satuan luas. Kepadatan masingmasing species pada setiap stasiun dihitung dengan menggunakan rumus Odum (1971). Struktur komunitas, yang berupa indeks keanekaragaman, keseragaman dan dominansi dihitung berdasarkan Odum (1971). Keanekaragaman menunjukkan keberagaman species. Sedangkan untuk mengetahui seberapa besar kesamaan penyebaran jumlah individu tiap species Echinodermata digunakan indeks keseragaman, yaitu dengan cara membandingkan indeks keanekaragaman dengan nilai maksimumnya, dengan rumus Indeks Equitabilitas (e) (Fachrul, 2007). Untuk mengetahui apakah suatu spesies yang mendominasi dapat di tentukan dengan indeks Dominansi dari Simpson (Odum, 1971)

\section{HASIL DAN PEMBAHASAN Komposisi Species Echinodermata}

Hasil penelitian menunjukkan terdapat 3 species dari kelas Echinoidea, 3 species dari kelas Ophiuroidea dan 1 species dari kelas Asteroidea (Tabel 1). Komposisi species Echinodea secara keseluruhan berdasarkan titik pengamatan lebih banyak ditemukan di titik ke-3 pada setiap stasiun dan periode pengamatan. Titik ke-3 berjarak kurang lebih 100-110 meter dari garis pantai. Daerah ini memiliki kedalaman sekitar 10-30 cm saat surut terendah. Menurut Aziz (1996), Filum Echinodermata menempati semua habitat dan zonasi di ekosistem karang terutama yang selalu digenangi air pada saat waktu surut. Sedangkan pada titik ke-1 (jarak 0-10 m) dan ke-2 (jarak 5060) memiliki kedalaman 5-10 sentimeter saat surut terendah. Hal ini diduga memberikan pengaruh terhadap komposisi species Echinodermata pada kedua titik pengamatan tersebut. Di samping itu pada saat perairan mengalami surut terendah, pada titik ke-1 dan titik ke-2 banyak ditemukan aktivitas pengunjung di sekitar Pantai Krakal. Damayanti dan Ayuningtyas (2008), menambahkan bahwa pemanfaatan pantai karst di Kabupaten Gunung Kidul secara umum difungsikan untuk kegiatan pariwisata.

Species Asteriodea yang ditemukan di lokasi penelitian adalah Archaster typicus yang memiliki sisi aboral yang terdiri atas madreporit sebagai sistem sirkulasi air dan anus. Pada bagian oral dapat ditemukan mulut, bukaan ambulakral dan kaki tabung berbentuk silinder. Warna dari 
sampel yang ditemukan yaitu abu-abu dan cokelat bintik-bintik. Tubuh A. typicus ditutupi oleh duriduri pada bagian inferolateral (Gambar 2). Bintang laut ini biasanya memiliki lima buah lengan dengan tubuh yang pipih. Lengan $A$. typicus berbentu kruncing dan umumnya terdapat belang cokelat yang melintang. Spesies ini memiliki warna duri putih, berbentuk tumpul dan pipih. Spesies ini tersebar di selatan Samudera Hindia, Mascarene, timur Afrika (Madagaskar) Maldive, Teluk Bengal, timur India, utara Australia, Filipina, Cina, Jepang, Selatan Pasifik dan Hawai (Clark dan Rowe 1971).

Kelas Asteroidea memiliki kepadatan relatif yang paling sedikit yang ditemukan di lokasi penelitian. Kelas ini umumnya ditemukan di daerah berpasir, padang lamun, dan daerah terumbu karang yang selalu digenangi ait. Pada habitat yang mengalami kekeringan pada saat air surut terendah, terjadi beberapa penyesuaian, antara lain membenamkan diri dalam pasir (Groves dan Hunt, 1980). Menurut Aziz (1996), beberapa species Asteroidea menyukai dasar berlumpur, ini berkaitan dengan kebiasaan makannya sebagai pemakan endapan (deposit feeder). Selain itu, menurut Ruswahyuni (2010), perairan terbuka adalah perairan yang tidak terlindung serta dipengaruhi oleh ombak dan gelombang. Akibat dari arus dan gelombang menimbulkan turbulensi pada perairan terbuka dan terjadi pengadukan substrat dasar pada perairan tersebut yang akan mempengaruhi organisme yang terdapat di dalamnya.

Dari Kelas Echinoidea ditemukan tiga species dari genus Echinometra, yaitu E. mathaei, E. oblonga dan E. Viridis. E. mathei dapat mencapai diameter $5 \mathrm{~cm}$ dengan warna cangkang dan duri bervariasi. Warna pada cangkang dominan berwarna gelap dan berbentuk oval dilengkapi dengan duri pendek dan tumpul. $E$. mathei menggunakan duri dan gigi untuk mencari makan dan menggali lubang di area rataan karang. Biota ini merupakan nocturnal (aktif mencari makan di malam hari). Habitat biota ini di pantai

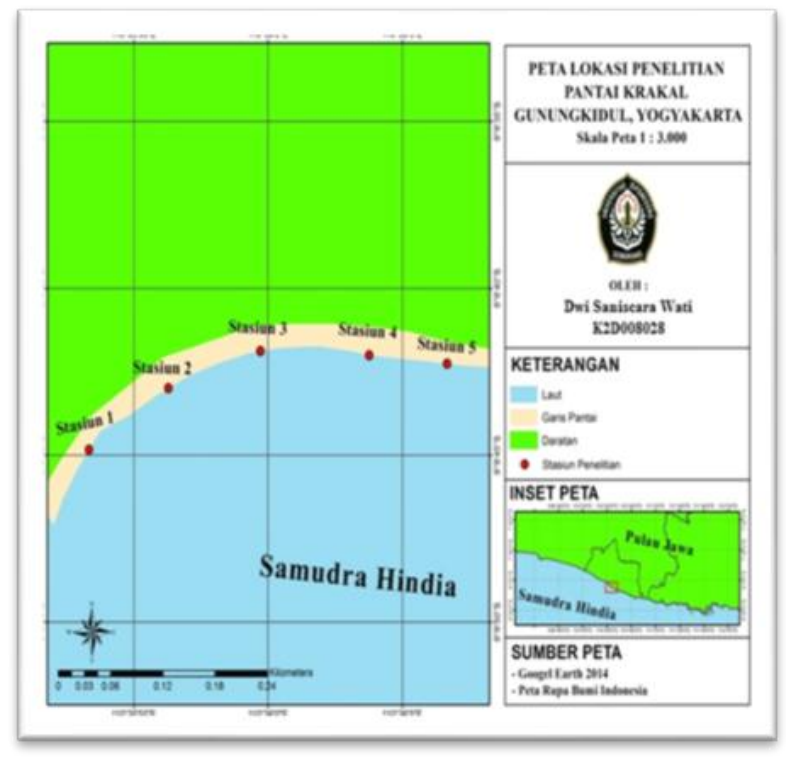

Gambar 1. Lokasi penelitian di pantaiu Krakal, Gunung Kidul.

Tabel 1. Species Echinodermata yang ditemukan Pantai Krakal, Gunung Kidul

\begin{tabular}{lllll}
\hline Kelas & Ordo & Famili & Genus & Spesies \\
\hline Asteroidea & Valvatida & Archasteridae & Archaster & A.typicus \\
Echinoidea & Camarodonta & Echinometridae & Echinometra & $\begin{array}{l}\text { E. mathaei } \\
\text { E. oblonga } \\
\end{array}$ \\
& & & E. viridis \\
Ophiouroidea & Ophiurida & Ophiocomidae & Ophiocoma & $\begin{array}{l}\text { O. erinaceus } \\
\text { O.scolopendrina }\end{array}$ \\
& & & & O. riseii \\
& & & & O. affinis \\
\hline
\end{tabular}




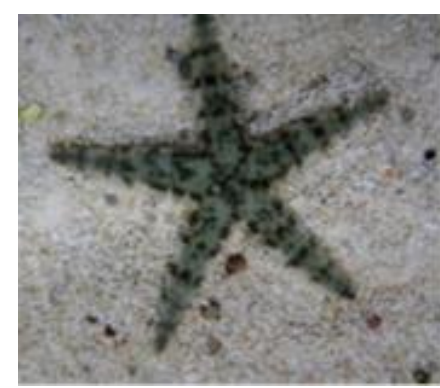

Archaster typicus

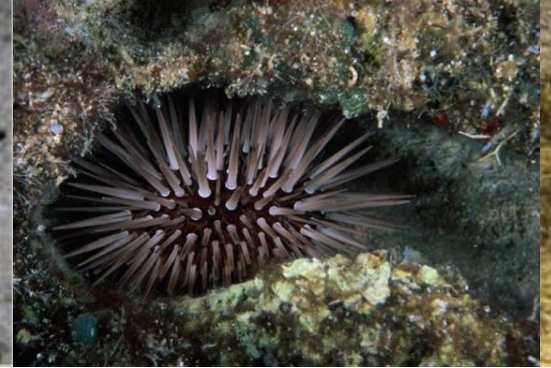

Echinometra mathaei

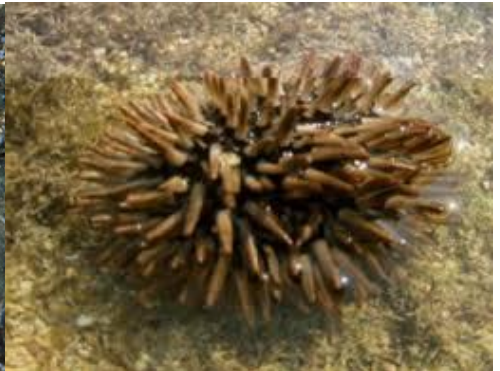

Echinometra oblonga

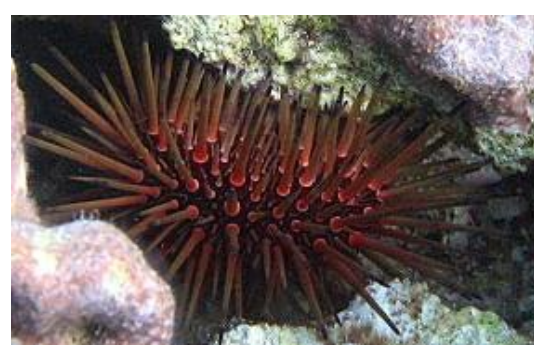

Echinometra viridis

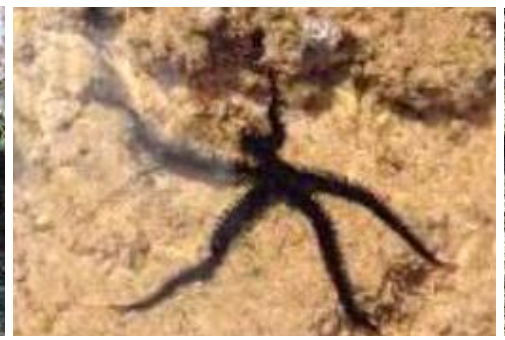

Ophiocoma erinaceus

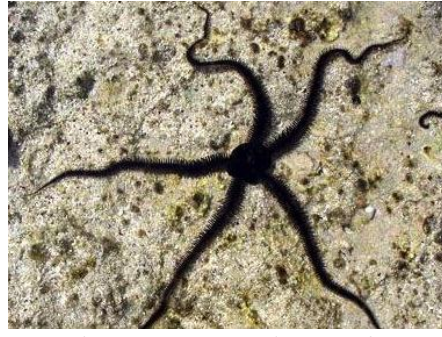

Ophiocoma scolopendrina

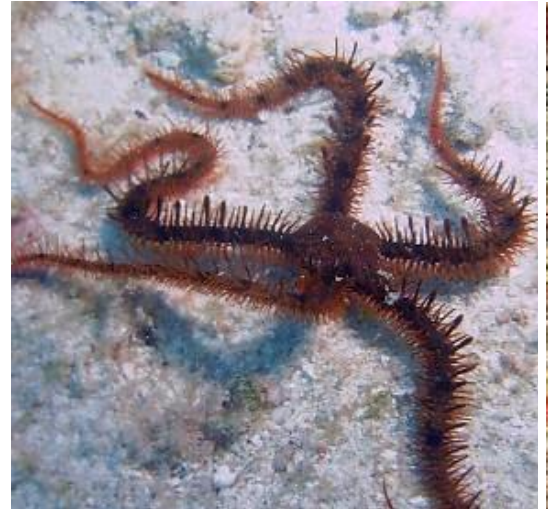

Ophiocoma riseii

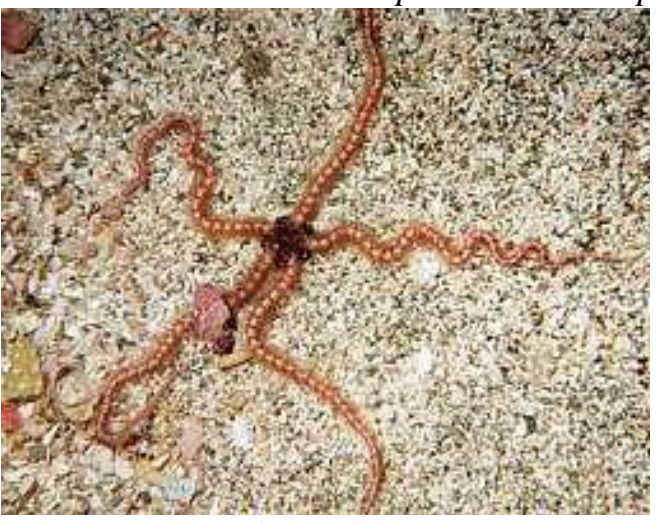

Ophiarachna affinis

Gambar 2. Species echinodermata yang ditekulan di Pantai Krakal, Gunung Kidul

berbatu dan di daerah rataan karang. Distribusinya di perairan dangkal yang tersebar di Samudera Indo-Pasifik di daerah Madagaskar, Pantai di Afrika Timur dan di Laut Merah dan Hawaii (Kroh \& Mooi, 2010). Juga terdistribusi di Kepulauan Marshall, Okinawa, Kepulauan Solomon, Papua Nugini, India, Pakistan, Maldive, Ceylon, Teluk Benggala, Samudera Hindia, Australia Utara, Filipina, Cina, dan Jepang Selatan (Clark \& Rowe, 1971) dan ditemukan juga di Indonoor Wreck, Pulau Kemujan, Kepulauan Karimunjawa (Hadi et al., 2011).. E. oblonga memiliki kesamaan dengan E. mathaei tetapi E. oblonga memiliki ukuran yang lebih kecil daripada E. mathaei. Warna cangkang gelap dan panjang diameter $5-20 \mathrm{~cm}$. Duri-durinya sangat kuat namun sangat tumpul dan pendek dan panjang duri dapat mencapai $2.5 \mathrm{~cm}$. E. oblonga merupakan hewan pemakan alga yang menempel pada rataan karang dan batuan, dan juga memakan detritus (Kroh \& Mooi, 2010). Habitat hidup di perairan dangkal di rataan karang, kawasan terumbu karang, dan batuan. Dapat ditemukan di Hawaii dan perairan Indo-Pasifik, Afrika selatan, Tanzania (Kroh \& Mooi, 2010). E. viridis berbentuk ellips dan berwarna merah kecoklatan dan warna tubuh biasanya merah (maroon) dan memiliki ukuran $5 \mathrm{~cm}$ dan panjang duri $3 \mathrm{~cm}$. Biasanya duri berwarna coklat terang sedikit merah. Diameter 5-20 cm dan panjang duri sekitar $3 \mathrm{~cm}$. Mencari makan alga dengan melubangi karang menggunakan gigi yang terdapat di sekeliling mulut dan merupakan biota yang aktif pada malam hari (Courtney et al., 2012). Habitat terdapat di area terumbu karang, bersembunyi sepanjang hari dan aktif mencari makan alga pada malam hari. Distrubusi di seluruh area Caribbian (McClanahan, 1999).

Hasil penelitian menunjukkan Kelas Ophiouroidea memiliki kepadatan relatif yang 
lebih banyak dibandingkan kelas lainnya. Yusron (2010) menyatakan bahwa kelompok Ophiouroidea dapat hidup menempati berbagai macam habitat dan kedalaman, seperti zona rataan terumbu karang, daerah pertumbuhan alga, padang lamun, koloni karang hidup, dan karang mati serta berbagai macam kedalaman mulai dari kedalaman satu meter sampai ribuan meter. Hal ini juga diperkuat oleh Stohr et al. (2012) yang mengungkapkan bahwa Kelas Ophiouroidea hidup di antara celah karang dan lubang-lubang karang dan dapat ditemukan mulai dari daerah intertidal sampai kedalaman lebih dari 6.500 meter. Terdapat 3 species dari genus Ophiocoma, yaitu $O$. Erinaceus, O. Scolopendrina dan $O$. riseii dan 1 species dari genus Ophiarachna, yaitu $O$. affinis. Menurut Oak and Schiebling (2006), spesies dari Genus Ophiocoma merupakan spesies yang paling melimpah diantara Bintang Mengular yang lain pada zona intertidal.

$O$. erinaceus umumnya memiliki warna hitam seragam di seluruh tubuh dan memanjang, memiliki duri yang tebal dan pendek di bagian lengan. Kaki tabung berwarna krem (Humphreys, 1981). O. erinaceus adalah hewan holotype dan memiliki diameter kurang lebih $17 \mathrm{~mm}$ dan panjang lengan mencapai $12 \mathrm{~cm}$, diameter cakram $20 \mathrm{~mm}$, berbentuk pentagonal dengan sedikit interradial di setiap sisi. Bagian cakram dorsal ditutupi dengan granula dengan diameter $0,15 \mathrm{~mm}$ dan merupakan hewan nocturnal (aktif mencari makan di malam hari) dan hewan bentik. Habitat ditemukan pada rataan terumbu karang, daerah padang lamun bersubstrat pasir dan pecahan karang di perairan dangkal dan area sublitoral karang seperti: terumbu karang, beting karang (Deloach \& Humann, 2012). Tersebar di IndoPasifik, Maldive, Ceylon, Teluk Bengal, India Timur, Australia Utara, Filipina, Cina, Jepang utara, Pasifik Selatan, Pulau Hawaii, Australia, dan India. Species ini juga ditemukan di selatan Pulau Tikus, Gugusan Pulau Pari, Kepulauan Seribu, Jakarta (Triana et al., 2015).

$O$. scolopendrina memiliki warna yang bervariasi. Cakram ventral memiliki warna yang lebih terang dan bervariasi. Panjang lengan mencapai $13 \mathrm{~cm}$, diameter cakram mencapai 20 $\mathrm{mm}$. O. scolopendrina terdiri atas 5 lengan yang berfungsi untuk menangkap partikel makanan pada permukaan perairan saat pasang surut (Humphreys, 1981). Habitat ditemukan pada dasar perairan (bentik) dan di daerah litoral, di celahcelah batuan besar. Persebaran umum dari Laut Merah Polynesia, Samudera Pasifik, perairan litoral, perairan tropis, Indo-Pasifik, Perairan
Afrika Timur ke Pulau Hawaii (Humphreys, 1981). O. riseii memiliki warna yang homogen yaitu hitam dan coklat kemerahan dan panjang lengan dapat mencapai $35 \mathrm{~cm}$. Struktur tubuhnya terdiri dari dorsal, ventral, dan lengan lateral dimana setiap amblukral dilengkapi dengan osikula. Lengan dorsal berwarna hitam dengan duri halus berwarna coklat kemerahan. Cakram ventral memiliki warna yang lebih terang. Cakram berbentuk pentagonal dan diameter $15 \mathrm{~mm}$ dan panjang lengan dapat mencapai $35 \mathrm{~cm}$. O. riisei bersembunyi di celah-celah batuan karang dan merupakan pemakan detritus dan material organik (Jones \& Endean, 2012). Habitat hidup pada rataan terumbu dan karang mati (Tommasi, 1970), alga berkapur, di semua zona karang, mangrove, padang lamun, di bawah batu, di koloni karang, dan di bawah spons (Hendler et al.,1995). Distribusi tersebar di daerah Bermuda, Bahamas, dan pulau-pulau di Florida bagian selatan, Texas, Antilles, Mexico, Indo-Pasifik (Hendler et al., 1995). O. affinis memiliki warna dasar krem dan terdapat duri pada lengan biasanya berwarna putih dan abu-abu yang memanjang sampai duri pada ventral. Panjang lengan mencapai $9 \mathrm{~cm}$ dan diameter cakram $2.5 \mathrm{~cm}$. Corak pada lengan berwarna krem dan abu-abu disertai dengan garis berwarna gelap dan merupakan hewan bentik (Sloan et al., 1979). Habitat ditemukan pada perairan dangkal area pecahan karang. Distribusinya di perairan tropis, wilayah Samudera Pasifik hingga kedalaman $25 \mathrm{~m}$, Laut Merah, Pasifik Timur, India Timur, Filipina, Pasifik Selatan, dan Australia.

Kelas Holothuroidea tidak ditemukan pada lokasi penelitian diduga dipengaruhi oleh beberapa faktor seperti penghindaran dari predator, kompetisi, dan pemilihan habitat spesifik yang bisa saja terjadi. Kelas Ophiouroidea dan Kelas Echinoidea hampir ditemukan di setiap periode pengambilan sampel, stasiun dan titik pengamatan. Kebanyakan anggota kelas Ophiuroidea dan Echinoidea dalam penelitian ini dijumpai bersembunyi di balik atau di antara tumpukan batu dan pecahan karang. Menurut Aziz (1996) Kelas Ophiouroidea dan Kelas Echinoidea bersembunyi pada beting karang untuk menghindari kekeringan saat surut dan sinar matahari. Sedangkan Kelas Holothuroidea pada umumnya ditemukan di daerah bersubstrat pasir (Nybakken, 1988). Brusca et al., (2003) menambahkan beberapa anggota Echinoidea memiliki perilaku yang hampir sama dengan Ophiuroidea, yakni memilih untuk bersembunyi di dalam lubang bebatuan dan 
pecahan karang mati sebagai mikrohabitatnya, tetapi ada juga yang memilih hidup bebas, soliter menjelajah perairan atau beragregasi membentuk kelompok populasi.

\section{Keanekaragaman, Keseragaman dan Dominansi}

Pola Indeks ekologi menunjukkan bahwa waktu pengamatan umumnya memiliki indeks keanekaragaman rata-rata dengan kategori sedang $(1,09)$, indeks keseragaman rata-rata dengan kategori yang tinggi $(0,82)$ dan secara umum nilai indeks dominansi rata-rata tidak ada dominansi 0,4). Krebs (1978), menjelaskan bahwa indeks keanekaragaman dapat digunakan untuk menyatakan hubungan kelimpahan spesies dalam suatu komunitas. Keanekaragaman spesies terdiri dari jumlah spesies dalam komunitas (kekayaan spesies dan kesamaan spesies). Kesamaan (menunjukkan bagaimana kelimpahan spesies itu (jumlah individu ataupun biomassa) yang tersebar diantara banyaknya spesies. Poole (1974) menambahkan bahwa nilai keanekaragaman tidak hanya dilihat dari banyaknya species tapi juga dari banyaknya penyebaran individu dalam setiap speciesnya dan tergantung dari kelimpahan individu dalam spesies.

Nilai Indeks keseragaman jika mendekati nilai 0 , maka dalam ekosistem ada kecenderungan terjadinya dominansi spesies yang disebabkan oleh adanya ketidaksedangan faktor-faktor lingkungan dan populasi. Bila Indeks keseragaman mendekati nilai 1, maka hal ini menunjukkan bahwa ekosistem tersebut dalam kondisi yang relatif sedang yaitu jumlah individu

Tabel 2. Komposisi Kehadiran dan frekuensi Species Echinodermata di Pantai Krakal

\begin{tabular}{|c|c|c|c|c|c|c|c|c|c|c|c|c|c|c|c|c|}
\hline & \multicolumn{3}{|c|}{ Stasiun 1} & \multicolumn{3}{|c|}{ Stasiun 2} & \multicolumn{3}{|c|}{ Stasiun 3} & \multicolumn{3}{|c|}{ Stasiun 4} & \multicolumn{3}{|c|}{ Stasiun 5} & \multirow{2}{*}{$\begin{array}{l}\text { FK } \\
(\%)\end{array}$} \\
\hline & 1 & 2 & 3 & 1 & 2 & 3 & 1 & 2 & 3 & 1 & 2 & 3 & 1 & 2 & 3 & \\
\hline \multicolumn{17}{|l|}{ Pengamatan Ke-I } \\
\hline Ophiocoma erinaceus & + & + & + & + & + & + & + & + & + & - & + & + & + & - & - & 80 \\
\hline Ophiocoma scolopendrina & - & + & + & + & + & + & + & + & + & + & + & + & + & - & - & 80 \\
\hline Ophiocoma riseii & - & - & - & + & - & - & + & + & + & + & + & - & - & - & - & 40 \\
\hline Ophiarachna affinis & - & - & - & - & + & - & - & + & + & + & + & + & - & + & + & 53,3 \\
\hline Archaster typicus & - & - & - & - & - & - & - & + & + & - & - & - & - & - & - & 10 \\
\hline Echinometra oblonga & - & - & - & - & - & + & - & + & - & - & - & + & - & - & - & 20 \\
\hline Echinometra viridis & - & - & - & - & - & - & - & - & + & - & - & + & - & - & - & 13,3 \\
\hline \multicolumn{17}{|l|}{ Pengamatan Ke-II } \\
\hline Ophiocoma erinaceus & + & + & + & + & + & + & + & + & + & - & + & + & + & + & + & 93,3 \\
\hline Ophiocoma scolopendrina & + & + & + & + & + & + & + & + & + & + & + & + & + & + & + & 100 \\
\hline Ophiocoma riseii & - & - & - & - & + & - & + & + & + & + & + & - & - & + & + & 53,3 \\
\hline Ophiarachna affinis & + & + & + & + & + & + & - & - & + & - & + & + & - & + & + & 73,3 \\
\hline Echinometra mathaei & + & - & + & + & + & + & + & + & + & + & - & - & - & + & + & 73,3 \\
\hline Echinometra oblonga & - & - & - & - & + & + & - & - & + & - & - & + & - & - & - & 26,6 \\
\hline Echinometra viridis & - & + & - & - & - & - & - & - & - & - & - & + & - & - & - & 13,3 \\
\hline \multicolumn{17}{|l|}{ Pengamatan Ke-III } \\
\hline Ophiocoma erinaceus & + & + & + & + & + & + & + & + & + & + & - & - & + & - & - & 73,33 \\
\hline Ophiocoma scolopendrina & + & + & + & + & + & + & + & + & + & + & + & - & + & - & - & 80 \\
\hline Ophiocoma riseii & - & - & - & + & + & - & + & + & + & - & + & - & + & - & - & 46,6 \\
\hline Ophiarachna affinis & - & - & - & - & - & - & - & - & - & - & - & - & - & - & - & 0 \\
\hline Echinometra mathaei & - & + & - & - & + & + & - & + & + & - & + & + & + & + & + & 66,6 \\
\hline Echinometra oblonga & + & + & - & - & + & + & - & - & + & - & - & + & - & + & + & 53,3 \\
\hline Echinometra viridis & - & - & + & - & - & - & - & - & + & - & - & + & - & - & - & 20 \\
\hline \multicolumn{17}{|l|}{ Pengamatan Ke-IV } \\
\hline Ophiocoma erinaceus & + & + & + & + & + & + & + & + & + & + & + & + & - & - & - & 80 \\
\hline Ophiocoma scolopendrina & + & + & + & + & + & + & + & + & + & + & + & + & - & + & - & 86,6 \\
\hline Ophiocoma riseii & - & - & + & - & - & - & - & + & + & - & - & - & - & - & - & 20 \\
\hline Ophiarachna affinis & - & - & + & + & + & + & - & + & + & + & + & + & + & + & + & 80 \\
\hline Echinometra mathaei & - & + & - & - & - & + & - & - & + & - & + & + & - & + & + & 46,6 \\
\hline Echinometra oblonga & - & - & - & - & - & - & - & - & - & - & - & - & - & - & - & 0 \\
\hline Echinometra viridis & - & - & - & - & - & - & - & - & + & - & - & + & - & - & - & 13,3 \\
\hline
\end{tabular}


Tabel 3. Parameter Lingkungan Pantai Krakal

\begin{tabular}{lll}
\hline \multicolumn{1}{c}{ Parameter } & \multicolumn{1}{c}{ Nilai Kisaran } & \multicolumn{1}{c}{ Kelayakan } \\
\hline Suhu air $\left({ }^{\circ} \mathrm{C}\right)$ & $29-32$ & $28-34$ (Azis, 1996) \\
Salinitas $(\%)$ & $31-33$ & $30-34 \%$ (Azis, 1981) \\
pH & $7-8$ & $7-8$ (Azis, 1996) \\
Kecerahan $(\mathrm{cm})$ & Sampai dasar & Sampai dasar \\
Kedalaman $(\mathrm{cm})$ & $10-30$ & $0->6500$ m (Sthor, 2012) \\
Substrat & Karang mati, pasir, pecahan karang & - \\
\hline
\end{tabular}

tiap spesies relatif sama atau tidak ada kecenderungan terjadi dominansi spesies (Brower $\&$ Zar, 1977). Semakin kecil keseragaman species dalam komunitas, artinya penyebaran jumlah individu setiap species tidak sama yaitu terdapat kecenderungan bahwa komunitas tersebut didominasi oleh sesuatu spesies atau species tertentu. Sebaliknya semakin besar nilai indeks keseragaman (menjauhi nol) dalam komunitas maka akan menyebabkan keseragaman species semakin besar, artinya kelimpahan setiap species dapat dikatakan sama atau tidak jauh berbeda dan di dalam komunitas tersebut tidak ada dominasi. Hasil pengamatan menunjukkan bahwa secara keseluruhan indeks similaritas dalam periode pengamatan hampir sama antar stasiunnya. Hal ini karena faktor ekologis dan faktor fisik kimia yang hampir sama antara setiap stasiun sehingga terdapatnya kesamaan nilai similaritas antar stasiun.

Pengukuran parameter lingkungan meliputi suhu, salinitas, $\mathrm{pH}$, kecerahan, kedalaman, pasang surut dan species substrat Tabel 3. Menurut hasil pengukuran bahwa kondisi lingkungan rata - rata tiap stasiun yang ada di Pantai Krakal sesuai dengan tempat hidup Echinodermata. Berdasarkan data pasang surut di Pantai Krakal selama bulan April hingga Juni tahun 2015, diketahui bahwa dalam wilayah perairan ini mengalami dua kali pasang dan dua kali surut dalam waktu 24 jam. Tinggi rendahnya pasang dan surut dalam periode tersebut bervariasi tergantung cuaca dan posisi bulan. Sedangkan untuk Kecepatan arus di Pantai Krakal sendiri pada bulan April 2015 mempunyai nilai rata-rata 7,07 cm/detik, pada bulan Mei 2015 kecepatan arus mempunyai nilai rata-rata $5,92 \mathrm{~cm} /$ detik dan pada Juni tahun 2015 mempunyai nilai rata-rata $4,01 \mathrm{~cm} /$ detik.

\section{KESIMPULAN}

Di Pantai Krakal Yogyakarta ditemukan 3 kelas dari filum Echinodermata. Spesies
Ophiocoma scolopendrina dan $O$. erinaceus paling sering dan hampir ditemukan di setiap titik pengamatan, dengan nilai frekuensi kehadiran rata-rata $84,15 \%$. Nilai Indeks Keanekaregaman $\left(\mathrm{H}^{\prime}\right)$ dan Keseragaman (e) echinodermata berturut-turut termasuk dalam kategori sedang $(1,09)$ dan tinggi $(0,65-0,93)$. Secara umum tidak ada dominansi species di daerah tersebut dengan indeks similaritas cukup tinggi antar stasiunnya. Hal ini karena faktor ekologis dan faktor fisik kimia yang hampir sama.

\section{DAFTAR PUSTAKA}

Azis, A. 1981. Fauna Echinodermata dari Terumbu Karang Pulau Pari, Kepulauan Seribu. Oseana, 14:41-90

Aziz. 1996. Habitat dan Zonasi Fauna Echinodermata di Ekosistem Terumbu Karang. Oseana 21(2):33-43.

Brower, J. E. \& J. H. Zar, 1977. Field and Laboratory Methods for General Ecology. Iowa : WM. J Brown Company Publ. Dubuque. $94 \mathrm{p}$.

Brusca, R. C \& G. J. Brusca. 2003. Invertebrates 2nd ed. Sinnauer associates Inc. publisher, hlm: 801-837

Clark, A. M. \& F. W. E Rowe. 1971. Monograph of Shallow-water Indo West Pasific Echinoderms. Trustees of the British Museum. London. p. 238.

Colin, P.L. \& C. Arneson, C. 1995. Tropical pacific invertebrates. The Coral Reef Research Foundation. CA, USA. 296 pp.

Courtney, T., Westfield I. \& Ries J. B. 2012. Echinometra viridis Exhibits Seasonal Response in Calcification Rates to Predicted end of 21st Century CO2-induced Ocean Acidification. Ocean acidification. EPOCA. Retrieved 2012-09-19.

Damayanti, A. \& Ayuningtyas, R. 2008. Karakteristik Fisik dan Pemanfaatan Pantai Karst Kabupaten Gunungkidul. Makara Teknologi 12(2): 91-98. 
Deloach, N. \& Humann, P. 2012. Reff Creature Identification Tropical Pacific. New World Publication, Inc. Jacksonville, Florida USA.

Dinas Pariwisata Daerah dan Kebudayaan Kabupaten Gunung Kidul. 2007. Buku: Data Potensi Kepariwisatan dan Kebudayaan Kabupaten Gunungkidul. Wonosari. Dinas Pariwisata dan Kebudayaan Gunungkidul.

Fachrul, M. F. 2007. Metode Sampling Bioekologi. Jakarta.

Fell, HB. 1960. Synoptic Keys to The Genera of Ophiuroidea. University of Wellington, New Zealand.

Gosliner, T.M., D.W. Behrens, \& G.C. Williams.

1996. Coral reef Animals of the Indo-Pasific. Sea Challengers, C.A. 314 pp.

Groves, D.G. and Hunt, L.M., 1980. Ocean world encyclopedia. McGraw-Hill.

Hadi, H., Hartati, R. \& Widianingsih. 2011. Fauna Echinodermata di Indonoor Wreck, Pulau Kemujan, Kepulauan Karimunjawa. Ilmu Kelautan (Indonesian Journal of Marine Sciences) 16 (4): 236-242

Hendler, G. L., M. P. Kier, J. E. Miller, and D. L. Pawson. 1995. Sea Stars, Sea Urchins, and Allies: Class Ophiuroidea. Smithsonian Institution Press. Washington. p. 89-195.

Humphreys, W. F. 1981. The Echinoderms of Kenya's Marine Parks and Adjacent Regions. Koninklijk Museum voor Midden-Africa (Tervuren, Belgium) Zoologische Documentatie 19. 39 pp.

Jones, O. A. \& Endean, R. 2012. Biology and Geology of Coral Reefs V3: Biology 2. Academic Press, Inc. London.

Krebs, C. J. 1985. Ecology: the Experimental Analysis of Distribution and Abundance. Harper And Rows Publication. New York. hlm: 800.

Kroh, A. \& Mooi, R. 2010. World Echinoidea Database. Accessed at http://www.marinespecies.org/echinoidea (10 Desember 2015).

Mann K. H. 1982. Ecology of Coastal Waters, Second Edition. Oxford: Blackwell Scientific Publication.

McClanahan T. R. 1999. Predation and the control of the sea urchin Echinometra viridis and fleshy algae in the patch reefs of Glovers Reef, Belize. Ecosystems 2: 511-523.

Nazir, M. 1988. Metodologi Penelitian. Jakarta: Ghalia Indonesia.
Nybakken, James. Wiley. 1988. Biologi Laut, Suatu Pendekatan Biologi. Jakarta. Gramedia.

Oak, T. \& Scheibling. R. E. 2006. Tidal Activity Pattern and Feeding Behaviour of the Ophiuroid : Ophiocoma scolopendrina on a Kenyan Reef Flat. Dalhousie University, Halifax, NS. Canada.

Odum, E. P. 1971. Fundamentals of Ecology. W.B. Sounders Company Ltd. Philadelphia.

Poole, R.W. 1974. An Introduction to Quantitative Ecology. Mc. Graw Hill Kogakusha, Ltd. Tokyo. p. 325.

Ruswahyuni. 2010. Populasi dan Keanekaragaman Hewan Makrobentos pada Perairan Tertutup dan Terbuka di Teluk Awur, Jepara. Jurnal Ilmiah Perikanan dan Kelautan, 2(1): 11-20.

Shannon, C. E. \& Wiener, W. 1963. The Mathematical Theory of Communication. University Illinois Press, Urbana, p. 360.

Sloan N. A., Clark, A. M. \& Taylor, J. D. 1979. The Echinoderms of Aldabra and Their Habitats. Bulletin of the British Museum (Natural History). Zoology 37(2): 81-128.

Stöhr. S., O'Hara. T. D., \& Thuy. B. 2012. Global Diversity of Brittle Stars (Echinodermata: Ophiuroidea). PLoS ONE 7(3): e31940. doi: 10.1371/journal.pone.0031940.

Suryabrata, S. 1992. Metode Penelitian. Universitas Gajah Mada. Rajawali. Yogyakarta. hlm: 234.

Tommasi, L. R. 1970. Os Ofiuróides Recentes do Brasil e de Regiôes Vizinhas. Contribuições Avulsas do Instituto Oceanografico, Univ. S. Paulo. Sér. Ocean Biol. 20: 1-146.

Triana, R., Elfidasari, D., Vimono, IB. 2015. Identifikasi Echinodermata di selatan Pulau Tikus, Gugusan Pulau Pari, Kepulauan Seribu, Jakarta. PROS SEM NAS MASY BIODIV INDON. 1(3): 455-459 DOI: 10.13057/psnmbi/m010313

Triutami, H.W. 2009. Keterlibatan Warga Pulau Pramuka Dalam Usaha Ekowisata Di Kepulauan Seribu. Tesis S1 Tidak Dipublikasikan, Insttitut Pertanian Bogor, Bogor.

Yusron, E. 2010. Keanekaragaman Species Ekhinodermata di Perairan Likupang, Minahasa Utara, Sulawesi Utara. Ilmu Kelautan (Indonesian Journal of Marine Sciences) 15 (2):85-90. 